\title{
PEMBELAJARAN MENULIS TEKS BIOGRAFI MELALUI PENDEKATAN SAINTIFIK DI KELAS VIII A1 DI SMP NEGERI 1 SINGARAJA
}

\author{
Kadek Ayu Fitriani ${ }^{1}$, I Made Sutama ${ }^{2}$, I Made Astika ${ }^{3}$ \\ Jurusan Pendidikan Bahasa dan Sastra Indonesia \\ Fakultas Bahasa dan Seni \\ Universitas Pendidikan Ganesha \\ e-mail:\{ayukadek8851@gmail.com, imadesutamaubd@gmail.com, \\ Tulanggadang@yahoo.com\}
}

\begin{abstract}
ABSTRAK
Penelitian ini bertujuan mengetahui pembelajaran menulis teks biografi melalui pendekatan saintifik di kelas VIII A1 di SMP Negeri 1 Singaraja dan untuk mengetahui hambatan-hambatan yang dihadapi siswa dalam belajar menulis teks biografi melalui pendekatan saintifik di kelas VIII A1 di SMP Negeri 1 Singaraja. Penelitian ini menggunakan rancangan deskriptif kualitatif. Subjek penelitian ini adalah guru Bahasa Indonesia yang mengajar di kelas VIII A1 di SMP Negeri 1 Singaraja dan siswa kelas VIII A1 di SMP Negeri 1 Singaraja. Objek penelitian ini adalah proses belajar mengajar guru dan siswa dikelas VIII A1 di SMP Negeri 1 Singaraja dalam menulis teks biografi melalui pendekatan saintifik dan hambatan-hambatan yang dihadapi siswa dalambelajar menulis teks biografi melalui pendekatan saintifik di kelas VIII A1 di SMP Negeri 1 Singaraja. Metode pengumpulan data yang digunakan adalah metode observasi dan wawancara. Hasil penelitian ini menunjukkan, pelaksanaan pembelajaran menulis teks biografi melalui pendekatan saintifik pada siswa kelas VIII A1 di SMP Negeri 1 Singaraja sudah berlangsung baik sesuai dengan rencana pelaksanaan pembelajaran (RPP) yang dibuat oleh guru dan pada setiap kegiatannya terdiri dari beberapa aspek. Semua aspek yang ada pada RPP telah terlaksanadan berlangsung dari awal hingga akhir kegiatan belajar mengajar pada pertemuan mata pelajaran Bahasa Indonesia dalam materi menulis teks biografi. Hambatan yang dihadapi oleh siswa dalam belajar menulis teks biografi melalui pendekatan saintifik adalah kekurangmampuan siswa dalam menemukan ide dan membuat gaya cerita yang baik. Guru sudah memberikan alternatif untuk merangsang siswa dalam menemukan ide yang ditulis dan dikembangkan dalam menulis teks biografi.
\end{abstract}

Kata kunci: pelaksanaan, hambatan menulis, menulis teks prosedur, pendekatan saintifik

\section{ABSTRACT}

This study aims to find out the learning of biography text writing through scientific approach in VIII A1 class at SMP Negeri 1 Singaraja and to find out the obstacles faced by students in learning to write biographical text through scientific approach in VIII A1 class at SMP Negeri 1 Singaraja. This research uses qualitative descriptive design. The subjects of this study are Indonesian teachers who teach in VIII A1 class at SMP Negeri 1 Singaraja and grade VIII A1 students at SMP Negeri 1 Singaraja. The object of this study is the teaching and learning process of teachers and students in class VIII A1 in SMP Negeri 1 Singaraja in writing biographical texts through scientific approaches and obstacles faced by students in learning to write biographical text through scientific approach in class VIII A1 in SMP Negeri 1 Singaraja. Data collection methods used were observation and interview methods. The results of this study indicate that the implementation of biographical text writing lesson through scientific approach in grade VIII A1 students at SMP Negeri 1 Singaraja has been going well in accordance with the learning implementation plan (RPP) made by teachers and in each activity consists of several aspects. All aspects of the lesson plan have been implemented and lasted from the beginning to the end of the teaching and learning 
activities at the Indonesian language meeting in biographical writing materials. The barriers faced by students in learning to write biographical texts through a scientific approach is the lack of ability of students to find ideas and create good story styles. Teachers have provided an alternative to stimulate students to find ideas written and developed in writing biographical texts.

Keywords: implementation, writing barriers, text-writing procedures, scientific approaches

\section{PENDAHULUAN}

Menulis merupakan suatu keterampilan berbahasa yang digunakan untuk berkomunikasi secara tidak langsung. Dalam menulis, kita dituntut untuk menguasai kosa kata, pengetahuan, pengalaman agar kita dapat menyampaikan gagasan-gagasan kita dengan baik kepada pembaca. Hal ini sejalan dengan pendapat yang disampaikan oleh Akhadiah dkk. (2009:1) bahwa melalui kegiatan menulis kita dapat mengembangkan gagasan. Ini berarti kegiatan menulis dapat membantu seseorang mengembangkan gagasan yang ada dalam pikirannya. Agar gagasannya tersebut dapat diketahui oleh orang lain, ia dapat menuangkannya dalam bentuk tulisan. Dengan menulis, gagasannya dapat dibaca dan kemudian dapat dipahami oleh orang lain.

Salah satu keterampilan berbahasa yang diajarkan di sekolah adalah menulis. Menulis mempunyai peranan penting dalam dunia pendidikan. Keterampilan menulis merupakan komponen keterampilan berbahasa yang perlu dibina dan dimiliki oleh siswa sejak memasuki pendidikan dasar hingga jenjang pendidikan yang lebih tinggi. Oleh karena itu, pada setiap tingkatan pendidikan terdapat standar kompetensi, yang menuntut siswanya untuk mampu menulis, baik itu keterampilan menulis sastra maupun nonsastra. Guru harus mampu menyeimbangkan antara menulis sastra dan nonsastra. Pembelajaran sastra tidak hanya menekankan pada pemberian teori saja tetapi juga praktik. Dengan kata lain, antara teori dan praktik harus berjalan seimbang.

Teks dalam Kurikulum 2013 dapat dibedakan antara teks sastra dan teks nonsastra dan berupa teks lisan maupun tulisan. Pada jenjang SMP/MTs terdapat 14 teks yang meliputi 3 teks sastra dan 11 teks nonsastra, yaitu (1) teks hasil observasi, (2) teks tanggapan deskriptif, (3) teks eksposisi, (4) teks eksplanasi, (5) teks cerita pendek, (6) teks cerita moral, (7) teks ulasan, (8) teks diskusi, (9) teks cerita prosedur, (10) teks cerita biografi, (11) teks eksemplum, (12) teks tanggapan kritis, (13) teks tantangan, (14) teks rekaman percobaan (Permendikbud No. 68 Tahun 2013). Namun, dalam penelitian dipilih satu teks untuk dijadikan bahan penelitian yakni teks biografi yang diajarkan di kelas VIII.

Peneliti juga menganggap bahwa menulis teks biografi penting dikuasai oleh siswa, karena selain diharapkan untuk memahami teks biografi, siswa nantinya harus dapat menyusun/menulis teks biografi secara mandiri sesuai dengan informasi yang didapat dari berbagai sumber tentang tokoh yangdi tulis biografinya, melalui menulis teks biografi siswa diharapkan mampu mengenal secara detil dan mendalam mengenai tokoh atau figur yang ditulis, tidak hanya itu, siswa nantinyamendapatkan pengalaman baru dibidang menulis teks dari kegiatan menulis teks sebelumnya karena kegiatan menulis teks biografi tentu berbeda dengan menulis jenis teks lain dan teks biografi muncul pada silabus mata pelajaran bahasa Indonesia kurikulum 2013. Apabila siswa terampil dalam menulis, ia dianggap telah menguasai aspek-aspek yang memengaruhi keterampilan menulis seperti aspek berbicara maupun keterampilan reseptif yaitu aspek membaca dan menyimak serta pemahaman kosa kata, diksi, keefektifan kalimat, penggunaan ejaan, dan tanda baca. Semi (1990:10) menyatakan bahwa menulis sebagai salah satu keterampilan berbahasa adalah kegiatan perekam bahasa lisan berbentuk tulisan. 
Keterampilan menuangkan karya dalam bentuk tulisan tidak didapatkan begitu saja melainkan diperoleh melalui proses yang disebut belajar, terutama mata pelajaran Bahasa Indonesia yang mencakup aspek keterampilan menulis. Proses pembelajaran untuk memeroleh keterampilan menulis ditempuh melalui tahapan-tahapan yang telah ditentukan. Salah satu tahapan yang harus ditempuh adalah tahapan memahami materi pelajaran, dalam hal ini materi yang dimaksud adalah materi teks menulis biografi. Pemahaman materi merupakan kemampuan seseorang untuk menangkap makna dan arti dari bahan yang dipelajari, yang dinyatakan dengan menguraikan isi pokok dari suatu bacaan atau mengubah data yang disajikan dalam bentuk tertentu ke bentuk yang lain. Sementara Benjamin S. Bloom (dalam Sudijono, 2009: 50) mengatakan bahwa pemahaman (Comprehension) adalah kemampuan seseorang untuk mengerti atau memahami sesuatu setelah sesuatu itu diketahui dan diingat. Dengan kata lain, memahami adalah mengerti tentang sesuatu dan dapat melihatnya dari berbagai segi. Dengan memahami materi, siswa lebih mudah dalam menyusun sebuah tulisan karena hal-hal yang dibutuhkan dalam menulis seperti struktur dan kaidah kebahasaan suatu teks yang terdapat pada materi pelajaranmenuntun siswa untuk menulis dengan terampil.

Menulis teks biografi adalah teks paparan yang ditulis oleh orang lain. Teks ini ditulis dengan tujuan menyampaikan halhal yang dapat dijadikan keteladanan dari orang tersebut. Teks biografi ini biasanya merupakan teks pemaparan dari tokohtokoh terkenal. Proses penyusunan teks ini pun tidak sembarangan melainkan melalui pencarian data-data yang akurat. Menurut Susanto (2014: 217-219), struktur teks biografi terdiri atas : (1) orientasi, merupakan bagian awal dari sebuah teks biografi yang menceritakan mengenai tempat dan tanggal lahir tokoh serta masa kecil tokoh, (2) peristiwa atau masalah, dalam teks biografi, peristiwa atau masalah dapat di tuliskan menjadi beberapa paragraf dan berisi peristiwa hebat dan menakjubkan yang pernah dialami tokoh, (3) reorientasi, merupakan penutup dalam teks biografi. Reorientasi biasanya berisi opini si Penulis dan biasanya bersifat opsional (bisa ada atau tidak).

Pendekatan saintifik dalam pembelajaran adalah metode ilmiah yang dirancang sedemikian rupa agar peserta didik secara aktif memahami materi pelajaran, hukum atau prinsip melalui tahapan-tahapan mengamati (untuk mengidentifikasi atau menemukan masalah), merumuskan masalah, mengajukan atau merumuskan hipotesis, mengumpulkan data dengan berbagai teknik, menganalisis data, menarik kesimpulan dan mengomunikasikan konsep, hukum atau prinsip yang ditemukan. Pendekatan saintifik dimaksudkan untuk memberikan pemahaman kepada peserta didik dalam mengenal, memahami berbagai materi menggunakan pendekatan ilmiah, bahwa informasi bisa berasal dari mana saja, kapan saja, tidak bergantung pada informasi searah dari guru. Oleh karena itu, kondisi pembelajaran yang diharapkan tercipta diarahkan untuk mendorong peserta didik dalam mencari tahu dari berbagai sumber melalui observasi, dan bukan hanya diberi tahu oleh guru. Kurikulum 2013 mengarahkan pembelajaran yang berpusat kepada siswa (student center) bukan lagi berpusat kepada guru. Perubahan paradigma dalam proses pembelajaran siswa diberitahu menjadi mencari tahu bukanlah hal yang mudah dilakukan oleh guru (Masnur, 2008).

Adanya pendekatan saintifik merupakan tuntutan dari Kurikulum 2013. Pembelajaran saintifik merupakan pembelajaran yang mengadopsi langkahlangkah saintis dalam membangun pengetahuan melalui metode ilmiah. Penerapan pendekatan saintifik/ilmiah dalam pembelajaran menuntut adanya perubahan keadaan dan bentuk pembelajaran yang berbeda dengan pembelajaran konvensional. Pendekatan saintifik ini guru berusaha membelajarkan siswa untuk mengenal masalah, 
merumuskan masalah, mencari solusi atau menguji jawaban sementara atas suatu masalah/pertanyaan, dengan melakukan penyelidikan (menemukan fakta-fakta), dan pada akhirnya dapat menarik simpulan dan menyajikannya secara lisan maupun tulisan. Langkah selanjutnya, guru memulai kegiatan inti pembelajaran dapat dilakukan dengan menggunakan aktivitas pengamatan. Siswa dapat mengamati fenomena dalam bentuk video, gambar, kerangka berpikir, teks, bahkan fenomena sosial maupun alam. Dalam pendekatan saintifik berarti guru tidak cukup berbekal buku teks ke dalam kelas. Guru perlu selalu menyiapkan bahan pembelajaran yangsiswa amati sebelum melakukan aktivitas belajar. Guru tidak memulai dengan memberi tahu siswa sehingga guru tidak bertindak sebagai satu-satunya sumber belajar.

Menurut Hidayat (2014), melalui pendekatan saintifik/ilmiah, selain dapat menjadikan siswa lebih aktif dalam mengkonstruksi pengetahuan dan keterampilannya, kegiatan ini diyakini dapat mendorong siswa untuk melakukan penyelidikan guna menemukan fakta-fakta dari suatu fenomena atau kejadian. Artinya, dalam proses pembelajaran, siswa dibelajarkan dan dibiasakan untuk menemukan kebenaran ilmiah, bukan hanya diajak untuk beropini dalam melihat suatu fenomena.

Tahapan aktivitas belajar yang dilakukan pada pendekatan saintifik yakni: mengamati, kegiatan yang pertama adalah melakukan pengamatan atau observasi guna memperoleh suatu informasi. Informasi yang tentunya berkaitan dengan topik pelajaran. Siswa hendaknya mengetahui karakteristik dari apa yg diamati melalui panca indra mereka. Tahap kedua yakni menanya atau mengajukan pertanyaan. Pada tahap ini siswa perlu dilatih untuk merumuskan pertanyaan yang berkaitan dengan topik dan materi pelajaran saat kegiatan belajar mengajar berlangsung. Dalam hal ini guru dan siswa bersama-sama dapat saling mengajukan pertanyaan seputar topik pelajaran. Ketiga mengumpulkan informasi atau data. Proses belajar mengajar yang dengan menggunakan pendekatan ilmiahmelibatkan siswa dalam melakukan aktivitas mengamati suatu peristiwa/fenomena guna menjawab suatu permasalahan. Data yang berupa informasi yang diperoleh dari berbagai sumber baik itu buku, media cetak, iternet dan sumber lainnya, kemudian siswa dapat melaporkan hasil aktivitas yang telah dilakukan tadi kepada guru serta teman lainnya. Keempat mengasosiasi/menalar, pada tahap ini seluruh informasi yang tadinya sudah diperoleh kemudian diolah umtuk menghubungkan keterkaitan antara topik dengan seluruh informasi yang diperoleh, aktivitas ini memerlukan ketelitian yang bersifat empiris dan sangat memerlukan logika dalam hal ini. Tahap akhir ialah komunikasi, tahap ini siswa diharapkan mampu mengomunikasikan apa yang telah dikerjakan pada tahap sebelumnya, terutama setelah melakukan aktivitas menalar tadi. Seluruh komponen yang diperoleh dapat disampaikan secara terbuka oleh salah satu siswa dan nantinya siswa lainnyamemberikan argumen atau komentar berdasarkan hasil serta informasi yang telah diperoleh berdasarkan tahaptahap sebelumnya.

Mata pelajaran bahasa Indonesia dalam Kurikulum 2013 menggunakan pendekatan berbasis teks, pendekatan ini bertujuan agar siswa mampu memproduksi dan menggunakan teks sesuai dengan tujuan dan fungsinya. Pembelajaran bahasa yang berbasis teks, sangat erat kaitannya dengan empat keterampilan dalam pembelajaran bahasa Indonesia khususnya. Empat keterampilan tersebut yakni: keterampilan membaca, keterampilan menulis, keterampilan menyimak, dan keterampilan berbicara. Dari keempat keterampilan tersebut keterampilan menulis merupakan kegiatan yang sangat penting untuk dikuasai karena menulis merupakan bagian yang tidak terpisahkan dalam seluruh proses pembelajaran yang dialami siswa selama menuntut ilmu baik itu di tingkat SD, SMP, maupun SMA. Terlebih lagi di bangku kuliah, mahasiswa wajib membuat karya 
tulis berupa tugas akhir, skripsi, atau tesis. Menulis sebagai salah satu keterampilan berbahasa adalah kegiatan perekam bahasa lisan berbentuk tulisan. Menulis sebagai kegiatan karena dengan menulis seseorang dapat mengungkapkan gagasan, maksud, ide, pesan, pengetahuan, ilmu, dan pengalaman sebagai suatu keterampilan yang produktif.

Mengingat pentingnya keterampilan menulis, peneliti tertarik untuk melakukan penelitian di SMP N 1 Singaraja. Mengapa di SMP N 1 Singaraja? Karena di SMP N 1 Singaraja merupakan sekolah yang telah menerapkan pendekatan saintifik sejak diberkakukannya kurikulum 2013 pada sekolah SMP, SMA dan sederajat di Indonesia yakni pada tahun ajaran 2013/2014. Selain itu mata pelajaran teks biografi juga muncul pada semester pertama di kelas VIII. Berdasarkan pengalaman peneliti selama mengobservasi di kelas VIII A1 di SMP Negeri 1 Singaraja, kemampuan menulis teks biografi siswa kelas VIII A1 di SMP Negeri1 Singaraja masih sangat rendah. Hal ini dapat terlihat dari kriteria ketuntasan minimal (KKM) siswa sebesar 79 , sedangkan kemampuan siswa dalam menulis teks biografi terdapat nilai yang paling rendah 75 dan yang paling tinggi 78. Hal tersebut dikarenakan oleh sulitnya siswa menemukan ide sebagai sumber menulis teks biografi. Hal itu dikarenakan oleh ketika peneliti mengobservasi di kelas VIII A1 di SMP Negeri Singaraja mengenai pembelajaran menulis teks biografi, siswa lebih asyik sendiri, tidur-tiduran, dan ada juga yang pikirannya menerawang jauh sehingga siswa kurang memperhatikan guru ketika menjelaskan.

Selain itu, berdasarkan hasil wawancara peneliti dengan salah satu guru, yang bernama Murti Ningsih, dinyatakan bahwa materi menulis teks biografi memang cukup susah dan hambatan siswa ketika menulis teks biografi, yaitu pertama siswa kurang mampu untuk menemukan ide. Kedua siswa kurang mampu membuat gaya cerita yang baik, ketika siswa ditugasi untuk membuat teks biografi. Selain itu, peneliti juga mewawancarai salah satu siswa kelas VIII A1 di SMP Negeri Singaraja yang bernama Febrin Winata menyatakan bahwa materi menulis teks biografi merupakan materi yang cukup susah dan ia mengatakan bahwa kendala yang dialaminya adalah dalam menuliskan kalimat dengan bahasa yang baik dan benar, agar gaya dalam cerita teks biografi menarik untuk dibaca. Berlandaskan kekurangan itulah, peneliti tertarik meneliti pembelajaran menulis teks biografi di kelas VIII A1 di SMP Negeri Singaraja dengan judul "Pembelajaran Menulis Teks Biografi melalui Pendekatan Saintifik di Kelas VIII A1 di SMP Negeri 1 Singaraja".

Penelitian pembelajaran menulis teks biografi pernah dilakukan di SMP Negeri 2 Kota Solok pada tahun 2014. Mega Putri Melia Rahmadona Tahun 2014 meneliti mengenai Kemampuan Menulis Teks Biografi Siswa Kelas VIII SMP Negeri 2 Kota Solok. Berdasarkan penelitian yang telah dijelaskan pada Bab IV, dapat disimpulkan bahwa semester pertama siswa kelas VIII SMP Negeri 2 Kota Solok pada tahun akademik 2015/2016 dalam menulis teks biografi didasarkan pada struktur teks mampu menulis teks biografi kualifikasi Lebih dari Cukup (LDC) dengan nilai rata -rata 69,57.

Penelitian di atas memiliki persamaan dengan penelitian yangpenliti lakukan, yakni sama-sama meneliti tentang menulis teks biografi. Perbedaan dengan penelitian yangpeneliti lakukan dilihat dari segi rancangan penelitian. Peneliti menggunakan rancangan penelitian deskriptif kualitatif, sedangkan penelitian Mega Putri Melia Rahmadona menggunakan rancangan penelitian deskriptif kuantitatif. Selain itu, perbedaan juga terlihat dari segi tempat meneliti. Peneliti meneliti di kelas VIII A1 SMP Negeri 1 Singaraja, sedangkan penelitian Mega Putri Melia Rahmadona meneliti di Kelas VIII SMP Negeri 2 Kota Solok. Selanjutnya perbedaan juga terlihat dari segi objek penelitian. Objek penelitian peneliti yakni pembelajaran menulis teks biografi melalui pendekatan saintifik dan hambatan-hambatan yang dihadapi oleh siswa dalam belajar menulis teks biografi 
melalui pendekatan saintifik, sedangkan objek penelitian Mega Putri Melia Rahmadona yakni siswa kurang minat dalam menulis, karena terlihat pada saat siswa latihan menulis, siswa banyak menyingkat-nyingkat kata, dan siswa kurang mampu dalam menulis teks, karena siswa tidak memahami struktur yang benar.

Selain itu, Siti Lutfiyah Tahun 2015 meneliti mengenai "Implementasi Pendekatan Saintifik pada Pembelajaran Teks Diskusi Siswa Kelas VIII di SMP Negeri 4 Singaraja". Hasil penelitian ini menunjukkan dua hal yakni (1) Implementasi pendekatan saintifik pada pembelajaran teks diskusi melalui beberapa tahap yaitu mengamati, menanya, mengumpulkan data, mencoba dan mengomunikasikan, dari kelima tahapan pendekatan saintifik tersebut tahapan mengumpulkan informasi dan mengolah informasi/mengasosiasikan tidak maksimal diterapkan oleh guru. (2) Hambatanhambatan yang dihadapi oleh guru dalam mengimplementasikan pendekatan saintifik ada pada tahap mengumpulkan informasi yakni kurangnya fasilitas yang memadai bagi siswa membuat siswa hanya mengandalkan fasilitas yang ada. Siswa hanya dapat mengandalkan pengetahuan mereka melalui buku paket siswa yang sudah disediakan. Hambatan tahap mengolah informasi juga dialami guru saat guru telah menjelaskan kepada siswa tentang tugas yangmereka kerjakan, masih banyak siswa yang bertanya dan hal tersebut membuat guru berulang kali menjelaskan. Kurangnya informasi dan sosialisasi tentang pendekatan saintifik, rendahnya keterampilan guru mengelola pembelajaran teks diskusi dengan penerapan pendekatan saintifik. Karakteristik dan kemampuan siswa yang berbeda sehingga, menyulitkan guru dalam mengimplementasikan pendekatan saintifik.

Penelitian di atas memiliki persamaan dengan penelitian yangpenliti lakukan, yakni sama-sama meneliti tentang pendekatan saintifik. Selain itu, persamaan terlihat juga dari segi rancangan penelitian yakni sama-sama menggunakan rancangan penelitian deskriptif kualitatif, sedangkan perbedaan dengan penelitian yangpeneliti lakukan dilihat dari segi objek penelitian. Objek penelitian peneliti yakni pembelajaran menulis teks biografi melalui pendekatan saintifik dan hambatanhambatan yang dihadapi oleh siswa dalam belajar menulis teks biografi melalui pendekatan saintifik, sedangkan obek penelitian Siti Lutfiyah yakni implementasi pendekatan saintifik pada pembelajaran teks diskusi dan hambatan-hambatan implementasi pendekatan saintifik pada teks diskusi. Selain itu, perbedaan juga terlihat dari segi tempat meneliti. Peneliti meneliti di kelas VIII A1 SMP Negeri 1 Singaraja, sedangkan penelitian Siti Lutfiyah meneliti di kelas VIII SMP Negeri 4 Singaraja. Kemudian, perbedaan terlihat juga dari segi metode pengumpulan data yang digunakan. Penelitian peneliti menggunakan metode pengumpulan data observasi, wawancara, dan dokumentasi, sedangkan penelitian Siti Lutfiyah menggunakan metode pengumpulan data observasi dan wawancara.

\section{METODE PENELITIAN}

Penelitian ini menggunakan rancangan deskriptif kualitatif. Penelitian ini dimaksudkan untuk memeroleh gambaran yang jelas, objektif, sistematis dan cermat mengenai fakta-fakta yang diperoleh berupa data terkait dengan judul pembelajaran menulis teks biografi melalui pendekatan saintifik di kelas VIII A1 di SMP Negeri1 Singaraja. Disamping itu, rancangan penelitian ini digunakan sebagai prosedur mengidentifikasi dan mendeskripsikan fenomena-fenomena yang terjadi di lapangan dengan objek tanpa adanya manipulasi data. Rancangan penelitian ini digunakan untuk mendeskripsikan tentang pembelajaran menulis teks biografi dan hambatanhambatan yang dihadapi siswa dalam menulis teks biografi melalui pendekatan saintifik di kelas VIII A1 di SMP Negeri 1 Singaraja.

Subjek penelitian adalah pihak-pihak yang dijadikan sebagai sampel dalam sebuah penelitian yang berperan memberikan tanggapan dan informasi 
terkait data yang dibutuhkan oleh peneliti. Arikunto (2002:116) subjek penelitian adalah benda, hal atau tempat variabel melekat, dan yang dipermasalahkan dalam penelitian. Pada penelitian ini adalah guru pengampu mata pelajaran Bahasa Indonesia di kelas VIII A1 di SMP Negeri 1 Singaraja dan siswa kelas VIII A1 di SMP Negeri 1 Singaraja. Objek penelitian adalah hal yang ingin dipahami secara lebih mendalam tentang "Apa yang terjadi" (Sugiyono, 2009:298). Objek penelitian ini adalah proses belajar mengajar yang dilakukan guru kepada siswa danhambatanyang dihadapi siswa dalam pembelajaran menulis teks biografi melalui pendekatan saintifik di kelas VIII A1 di SMP Negeri 1 Singaraja.

Metode pengumpulan data yang digunakan adalah metode observasi dan wawancara. Observasi adalah pengamatan mengenai fenomena secara sistematis kemudian dilakukan pencatatan. Metode observasi adalah metode penelitian dengan cara mengadakan pengamatan secara langsung terhadap gejala yang tampak pada objek penelitian (Suandi, 2008:39). Observasi yang peneliti lakukan tergolong observasi partisipasi pasif. Yang dimaksud dengan observasi partisipasi pasif adalah suatu observasi yang dilakukan oleh seorang peneliti dengan ikut berada dalam kegiatan yang diteliti, namun peneliti tidak berintraksi dengan subjek penelitian. Yang dilakukan peneliti hanyalah menempati pos tertentu, yang dalam penelitian ini peneliti berada di bangku paling belakang dari pos tersebut, penelitimelakukan pengamatan dan perekaman atas segala kejadian yang berlangsung (Spradley dalam Gosong, 1998:91).

Metode observasi digunakan untuk mengamati pelaksanaan pembelajaran menulis teks biografi di dalam kelas. Pelaksanaan pembelajaran di dalam kelas yang dibimbing oleh guru mengenai materi menulis teks biografi. Pertama-tama guru memberikan salam kepada siswa kemudian siswa menjawab salam guru. Kemudian, guru memberikan indikator, tujuan, dan materi pembelajaran. Selanjutnya, guru menjelaskan kepada siswa mengenai materi menulis teks biografi dengan menggunakan metode ceramah. Setelah menjelaskan, siswa diberikan contoh teks biografi. Tujuan guru menggunakan metode tersebut agar siswa dapat memahami teks biografi dan siswa bisa menulis teks biografi. Setelah guru menjelaskan, siswa ditugaskan untuk menulis teks biografi. Kemudian, setelah siswa selesai mengerjakan, siswa diperintahkan untuk mengumpulkan tugasnya. Kemudian, setelah siswa mengumpulkan tugas guru dan siswa bersama-sama menyimpulkan pembelajaran.

Wawancara adalah suatu bentuk komunikasi verbal yang bertujuan memperoleh informasi. Tujuan dilakukan wawancara untuk memperoleh konstruksi yang terjadi sekarang tentang orang, kejadian, aktivitas, organisasi, perasaan, motivasi, pengakuan, kerisauan, dan sebagainya. Rekonstruksi keadaan tersebut berdasarkan pengalaman masa lalu, proyeksi keadaan tersebut diharapkan terjadi pada masa yangdatang, dan Verifikasi, pengecekan dan pengembangan informasi (kontruksi, rekonstruksi, dan proyeksi) yang telah didapat sebelumya (Lincoln dan Guba, dalam Syamsuddin, 2009:94).

Wawancara dilakukan terhadap guru. Wawancara dilakukan berkaitan dengan hambatan-hambatan yang dihadapi oleh siswa dalam pembelajaran menulis teks biografi. Instrumen yang digunakan adalah pedoman wawancara tidak berstruktur, yakni pedoman wawancara yang tidak disediakan jawaban atas pertanyaan yang diajukan.

Dalam penelitian ini, metode analisis data dilakukan dengan beberapa langkah. Metode analisis data yang digunakan peneliti adalah teknik analisis deskriptif kualitatif (1) klasifikasi data, (2) reduksi data, (3) penyajian data, (4) penyimpulan. Mengklasifikasikan atau mengelompokkan data yang telah didapat sesuai dengan rumusan masalah yang diangkat. Dalam penelitian ini, klasifikasi data dilakukan berdasarkan data yang sudah didapat terkait dengan pembelajaran menulis teks biografi dan hambatan-hambatan yang 
dihadapi siswa dalam menulis teks biografi melalui pendekatan saintifik di kelas VIII A1 di SMP Negeri 1 Singaraja. Dalam menganalisis data, hal harus dilakukan adalah melakukan reduksi data sesuai dengan rumusan masalah penelitian. Reduksi data dilakukan karena besar kemungkinan banyak data-data yang tidak sesuai dengan permasalahan yang ingin dipecahkan. Mereduksi data berarti memilih hal-hal pokok, memfokuskan pada hal-hal penting, mencari temanya serta polanya dan membuang yang tidak perlu (Sugiyono, 2009: 38). Pada kegiatan reduksi data, peneliti memilih hal-hal pokok yang berkaitan dengan pembelajaran menulis teks biografi dan hambatanhambatan yang dihadapi siswa dalam menulis teks biografi melalui pendekatan saintifik yang telah didapat melalui proses observasi dan wawancara.

Setelah data digolongkan sesuai dengan rumusan masalah, selanjutnya data tersebut diolah dan dianalisis untuk memperoleh jawaban yang tepat yang sesuai dengan rumusan masalah. Pada gilirannya, data tersebut dapat menjawab permasalahan yang diangkat dalam penelitian ini. Data-data yang telah direduksi digambarkan secara detail dan jelas. Dalam penyajian ini, data yang didapat akan dihubungkan dengan teoriteori yang relevan yang nantinya dapat menjawab permasalahan yang ingin dipecahkan.

Penyimpulan sangat penting dilakukan dalam penelitian. Hal itu dikarenakan dengan penyimpulan dapat diketahui keakuratan penelitian. Penyimpulan yang dilakukan diharapkan dapat menjawab semua permasalahan yang diangkat dalam penelitian. Kegiatan ini merupakan tahap akhir dalam analisis data. Penyimpulan dalam penelitian ini dilakukan setelah data-data yang diperoleh disajikan. Penarikan simpulan ini dilakukan sehingga dapat diketahui tentang pembelajaran menulis teks biografi dan hambatan-hambatan yang dihadapi siswa dalam menulis teks biografi melalui pendekatan saintifik di kelas VIII A1 di SMP Negeri 1 Singaraja.

\section{HASIL DAN PEMBAHASAN \\ Hasil}

Hasil penelitian ini mencakup datadata tentang (1) Pelaksanaan pembelajaran menulis teks biografi melalui pendekatan saintifik siswa kelas VIII A1 di SMP Negeri 1 Singaraja dan (2) Hambatan-hambatan yang dihadapi oleh Siswa dalam belajar menulis teks biografi melalui pendekatan saintifik.

Pelaksanaan pembelajaran teks biografi melalui pendekatan saintifik sudah sesuai dengan indikator dalam pedoman. Adapun langkah-langkah pelaksanaan pembelajarannya dilihat dari segi (1) kegiatan pendahuluan, (2) kegiatan inti, (3) penguasaan materi pelajaran, (4) pemanfaatan media pembelajaran, (5)pemanfaatan alat pembelajaran, (6) pemanfaatan sumber belajar, dan (7) penutup. Dalam kegiatan inti guru memfasilitasi siswa melakukan proses mengamati, menanya, mengumpulkan data/ fakta/informasi dan pemodelan dan membangun teks secara bersama-sama, serta mengomunikasikan.

Guru menunjukkan penguasaan materi pembelajaran dengan cara guru menanggapi pertanyaan, memperjelas pertanyaan siswa agar dimengerti oleh siswa lain, dan mempertegas atau menambahkan jawaban siswa yang kurang lengkap serta menambahkan materi-materi teks biografi. Dalam pemanfaatan media pembelajaran guru menunjukkan efektifitas dan efisiensi penggunaan media pembelajaran dengan cara memfasilitasi siswa menggunakan teks biografi pada saat pembelajaran teks biografi. Selanjutnya, siswa menyampaikan pesan yang menarik pada contoh yang diberikan pada materi teks biografi, contoh yang belum pernah dibaca oleh siswa, sehingga memancing pertanyaan-pertanyaan berkaitan dengan contok teks biografi tersebut. Dalam pemanfaatan alat pembelajaran, guru menunjukkan efektivitas penggunaan alat pembelajaran pada materi teks biografi, guru memfasilitasi siswa memanfaat-kan LCD untuk menonton video. 
Dalam pemanfaatan sumber belajar, guru menunjukkan efektifitas penggunaan sumber belajar. Guru memperlihatkan pedoman yang digunakan, menggunakan buku pegangan siswa sebagai sumber pembelajaran siswa, dan memperlihatkan EYD sebagai acuan dalam menyusun teks.

Dalam pengelolaan kelas, guru menyesuaikan pengaturan tempat duduk peserta didik sesuai dengan tujuan dan karakteristik proses pembelajaran dengan cara menggunakan volume dan intonasi suara yang dapat didengar dengan baik oleh peserta didik dan menggunakan katakata santun, lugas, dan mudah dimengerti oleh peserta didik serta menyesuaikan materi pelajaran dengan kecepatan dan kemampuan belajar peserta didik. Kemudian, guru menciptakan ketertiban, kedisiplinan, kenyamanan, dan keselamatan dalam menyelenggarakan proses pembelajaran, memberikan penguatan dan umpan balik terhadap respons dan hasil belajar peserta didik selama proses pembelajaran berlangsung. Dalam kegiatan penutup, guru mengajak siswa membuat simpulan pembelajaran, merefleksi seluruh rangkaian aktivitas pembelajaran dengan cara memotivasi dan memberikan siswa umpan balik. Selanjutnya, guru melakukan kegiatan tindak lanjut dalam bentuk pemberian tugas, baik tugas individual maupun kelompok dengan cara memberikan kuis sederhana.

Ada beberapa hambatan yang dihadapi oleh siswa dalam belajar menulis teks biografi melalui pendekatan saintifik. Yang pertama adalah kekurangmampuan siswa dalam menemukan ide. Ide yang dimaksud adalah, gagasan yangdikembangkan menjadi sebuah tulisan yakni jenis teks biografi. Yang kedua adalah kekurang mampuan dalam membuat gaya cerita yang baik, ketika siswa ditugasi untuk membuat teks biografi. Dari pembahasan hasil tulisan siswa bersama guru, beberapa kelompok menemui permasalahan yang sama mengenai yakni kekurangmampuan siswa dalam menemukan ide dan membuat gaya cerita yang baik. Gaya cerita berperan penting dalam keberhasilan menulis teks biografi, sebab gaya cerita yang baik dan menarikmembuat pembaca tidak merasa bosan.

\section{Pembahasan}

Pembahasan hasil penelitian difokuskan pada temuan penting mengenai pembelajaran menulis teks biografi melalui pendekatan saintifik pada siswa kelas VIII A1 Di SMPN 1 Singaraja. Berdasarkan hasil observasi yang dilakukan, dapat dipaparkan pembelajaran menulis teks biografi melalui pendekatan saintifik secara lebih mendalam dalam pembahasan berikut.

Pelaksanaan pembelajaran menulis teks biografi melalui pendekatan saintifik siswa kelas VIII A1 di SMP Negeri 1 Singaraja diperoleh dari hasil observasi pembelajaran di kelas VIII A1. Observasi adalah metode penelitian dengan cara mengadakan pengamatan secara langsung terhadap gejala yang tampak pada objek penelitian (Suandi, 2008:39). Pembelajaran menulis teks biografi melalui pendekatan saintifik pada kelas VIII A1 SMPN 1 Singaraja tergolong baik. Mengapa demikian, karena pelaksanaan pembelajaran teks biografi melalui pendekatan saintifik dilaksanakan dengan cara melihat indikator aspek yang dinilai dalam pedoman yang berdasarkan pendekatan saintifik. Proses pelaksanaan pembelajaran guru secara umum, sudah berjalan dengan baik. Pelaksanaan pembelajaran guru dalam menulis teks biografi pada siswa kelas VIII A1 SMP Negeri 1 Singaraja mengacu pada langkahlangkah pembelajaran dalam RPP yang dibuat oleh guru. Langkah-langkah tersebut sudah sesuai dengan pendekatan scientific kurikulum 2013.

Hambatan yang dihadapi oleh siswa dalam pelaksanaan menulis teks biografi melalui pendekatan saintifik yang pertama adalah kekurang mampuan siswa dalam menemukan ide. Secara keseluruhan hal yang dinilai siswa ketika menulis, khususnya menyusun teks biografi yakni menemukan ide. Siswa tidak memiliki gambaran apa pun tentang hal yang mereka kembangkan untuk menjadi sebuah tulisan. Ketika menentukan apa yang 
dibuat, siswa lebih banyak berdiam sembari memikirkan topik yang kemudian disusun menjadi sebuah kerangka ide. Siswa kurang aktif dan tidak tahu banyak mengenai informasi-informasi berkaitan dengan tokoh yang dijadikan profil menulis teks biografi. Informasi yang dimaksud berupa identitas lengkap tokoh, riwayat hidup, prestasi, dan segala hal tentang tokoh. Siswa kurang membaca buku atau artikel tentang tokoh, selain itu pengalaman siswa yang kurang dalam menulis juga menjadi salah satu penyebab mengapa mereka bingung dan sulit menemukan ide untuk menulis teks biografi.

Yang kedua adalah kekurang mampuan siswa membuat gaya cerita yang baik, ketika siswa ditugasi untuk membuat teks biografi. Mengapa demikian, karena materi teks biografi tergolong materi yang cukup susah. Oleh karena itu, penguasaan atau pemahaman siswa terhadap materi pelajaran menulis teks biografi masih tergolong sangat rendah. Siswa sedikit bingung seperti apa ia akan memulai dan menyusun teks biografi berdasarkan tokoh yang mereka tentukan. Penguasaan topik, gaya tulis, dan pilihan diksi yang digunakan cenderung sama dan berulang-ulang, sehingga gaya cerita kurang menarik. Pilihan kata seperti, lalu, kemudian, setelah itu adalah diksi yang monoton digunakan dalam menceritakan riwayat tokoh. Siswa hendaknya memvariasikan pilihan kata yang digunakan ketika menulis teks biografi agar pembaca nantinya tidak bosan.

\section{PENUTUP}

\section{Simpulan}

Berdasarkan sajian analisis data dan pembahasan hasil penelitian yang dipaparkan dalam pembahasan dapat disimpulkan bahwa (1) Pelaksanaan pembelajaran menulis teks biografi melalui pendekatan saintifik siswa kelas VIII A1 di SMP Negeri 1 Singaraja sudah berlangsung sesuai dengan Rencana Pelaksanaan Pembelajaran (RPP) yang pada setiap kegiatannya terdiri dari aspek-aspek seperi, Kegiatan pendahuluan, kegiatan inti, penguasaan materi pelajaran, pemanfaatan media pembelajaran, pemanfaatan alat pembelajaran, pemanfaatan sumber belajar, pengelolaan kelas, dan kegiatan penutup. Semua aspek tersebut telah terlaksana dan berlangsung dari awal hingga akhir kegiatan belajar mengajar pada pertemuan mata pelajaran Bahasa Indonesia materi menulis teks biografi. (2) Hambatan yang dihadapi oleh siswa dalam belajar menulis teks biografi melalui pendekatan saintifik adalah kekurangmampuan siswa dalam menemukan ide dan membuat gaya cerita yang baik, ketika siswa ditugasi untuk membuat teks biografi. Berdasarkan hal tersubut guru memberikan alternatif untuk merangsang siswa dalam menemukan ide yangditulis dan dikembangkan dalam menulis teks biografi. Peranan guru ketika proses belajar mengajar berlangsung hanya sebagai fasilitator

\section{Saran}

Setelah penelitian ini dilaksanakan, peneliti dapat memberikan saran sebagai berikut. (1) Kegiatan pelaksanaan pembelajaran keterampilan menulis teks biografi melalui pendekatan saintifik siswa tergolong baik. Berdasarkan hasil tersebut, guru bahasa Indonesia agar lebih sering memberikan latihan-latihan dalam menulis teks biografi, baik disekolah maupun di rumah dengan cara memberikan pelatihanpelatuhan tugas ataupun pekerjaan rumah untuk menulis teks biografi kepada siswa. (2) Guru bahsasa Indonesia diharapkan agar memberikan penilaian terhadap latihan-latihan siswa dan hasil tersebut diperhitungkan dalam rapor sehingga siswa lebih bersemangat mengerjakan pelatihan karena ingin mendapatkan nilai yang baik. (3) Para peneliti atau pembaca yang berminat, dapat meneliti masalah ini lebih lanjut dalam lingkup yang lebih besar agar memperoleh hasil yang lebih sempurna dan dapat mengembangkan penelitian semacam ini dalam pembelajaran aspek lain dan jenjang sekolah yang lain pula. 
DAFTAR PUSTAKA

Akhadiah, dkk. 2009. Pembinaan Kemampuan Menulis Bahasa Indonesia. Jakarta: Erlangga.

Arikunto, Suharsimi, dkk. 2002. Prosedur Penelitian. Satuan Pendekatan Praktek (Edisi Revisi). Jakarta: Rineka Cipta.

Gosong, I Made. 1998. "Pertanyaan yang Diajukan oleh Guru dalam Pembelajaran Membaca". Disertasi (tidak diterbitkan). Malang: IKIP Negeri Malang.

Hidayat, Arifudin. 2014. "Penerapan Pendekatan Saintifik pada Mata Pelajaran Pendidikan Agama Islam untuk Peningkatan Prestasi Belajar Kelas IB SD N 1 Bantul". Tersedia pada http://digilib.uinsuka.ac.id.pdf (diunduh pada tanggal 12 Juni 2015).

Iskandar, Uray. 2011. Langkah-Langkah Kegiatan Pembelajaran.

(http://urayiskandar.com/2011/10/ langkah-langkah-kegiatanpembelajaran.html), (diakses tanggal 4 Juli 2018).

Semi, M. Atar. 1990. Kemampuan Menulis IImiah. Bandung: PT Adi Karya.

Suandi. 2008. Pengantar Metodelogi Penelitian Bahasa. Buku Ajar (belum diterbitkan). Singaraja: Universitas pendidikan Ganesha.

Sugiyono. 2009. Metode Penelitian Pendidikan (Pendekatan Kuantitatif, Kualitatif, dan R\&B). Bandung: Alfabet.

Susanto, Ready. 2014. Buku Paket XI SMA/SMK/MAK Bahasa Indonesia Kurikulum 2013. Bandung: Nuansa.

\begin{tabular}{llr}
\multicolumn{2}{c}{ Syamsudin. 2009. } & Metode \\
Penelitian & Pendidikan & Bahasa. \\
Bandung: & PT Remaja Rosdakarya.
\end{tabular}

Syamsudin. 2009. Metode Penelitian Pendidikan Bahasa. Bandung: $\quad$ PT Remaja Rosdakarya. 